\title{
Wacochachi's Talking Paper
}

Jack W. Musgrove

Mary R. Musgrove

\begin{abstract}
AN INDIAN PICTOGRAPH believed to date from the late 1820 s or early 1830 s has been discovered on two sheets of paper held together by sealing wax, folded and hidden in the pages of a book in the State Historical Library of Iowa.
\end{abstract}

The pictograph was found by two library

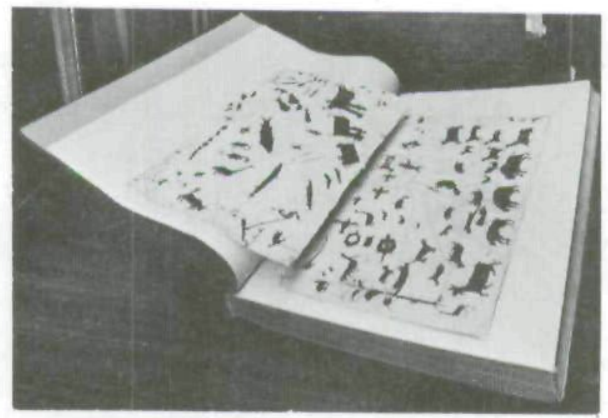

Des Moines Tribune photo by David Penney The pictograph as it was found in the pages of a book.

employees, Mrs. Phyllis McLaughlin and Mrs. Virginia Dochterman, during a routine inventory of books in the library collection. One volume of History of the Indian Tribes of North America, With Biographical Sketches and Anecdotes of the Principal Chiefs, by Thomas L. McKenney and James Hall-appropriately enough a book about Indians-fell open at the place where the folded paper had been placed.

This particular set of McKenney and Hall, one of several in the library collections, was presented to the Department in 1924 through the bequest of Naomi Davenport as a memorial to her father, George L. Davenport. Colonel Davenport was post trader

\section{HISTORY \& ARCHIVES \\ Historical Building DES MOINES, IOWA}




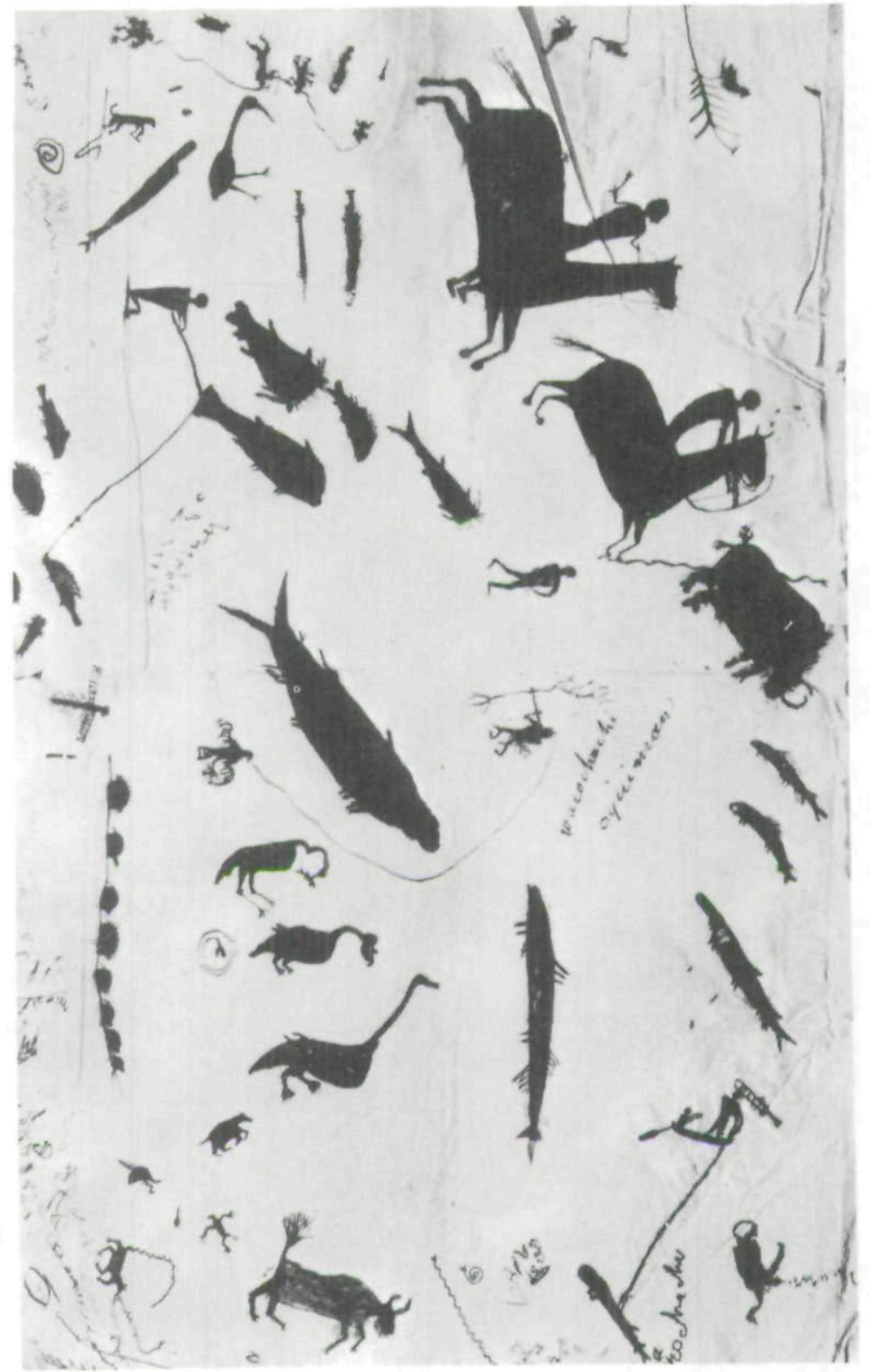




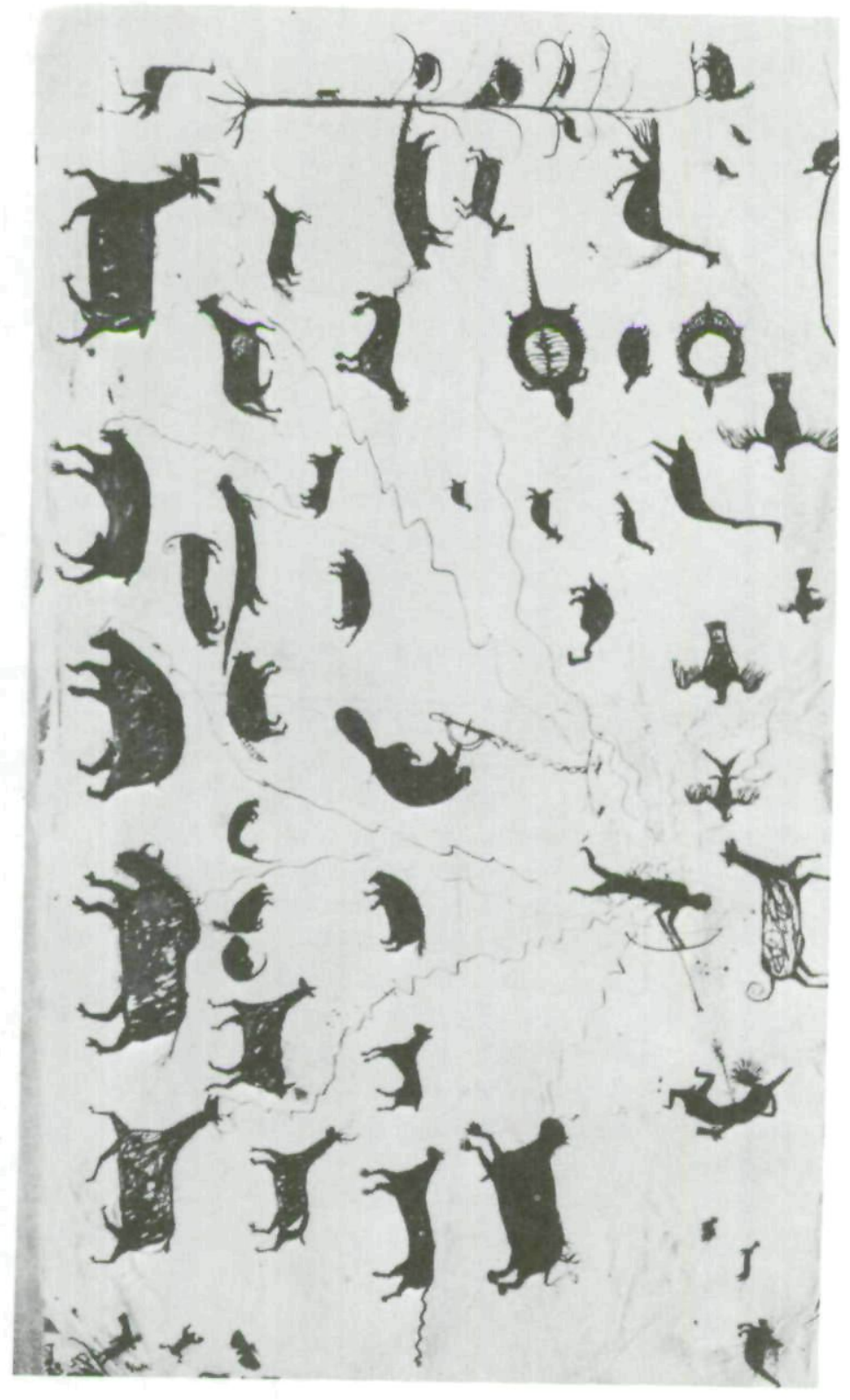


at Fort Armstrong, on an island in the Mississippi River where the Rock Island Arsenal now stands, beginning in 1816; he was the man for whom the city of Davenport is named. There is no doubt the volumes in question are those from the Davenport estate; all others have been rebound.

The pictograph probably remained undiscovered until 1973 simply because other sets of McKenney and Hall were available and this one didn't happen to be used. A picture of Colonel Davenport and two old pictures of the city were also found in the book.

The pictograph is done in black ink on white paper, now yellowed with age, and appears to have been kept in a desk for some time, since its edges are dog-eared, and later put in the book for safe keeping. Workers in the state museum carefully unfolded the pictograph and smoothed it out. In some places where the ink had eaten through the paper, thin paper was placed back of the weakened spot and the pictograph restored with India ink, but beyond this minimum restoration and reinforcement, no work has been done on it.

The pictograph appears to be a chronicle of a spring hunt, with the story beginning at about the center of each sheet of paper and moving in a circle around the sheet, as if the paper were turned as successive pictures were drawn.

On one sheet there is a sign for a river, a wavy line going toward the top of the page. ${ }^{1}$ Two Indians are pictured riding on horses, which are running, and one is shooting a buffalo with bow and arrow. The Indians are pictured on the left side of the river, which is probably the Mississippi, and best interpretation seems to be that they traveled northward on the west bank of the river (the fork at the end of the river line showing direction traveled). ${ }^{2}$ They rode horses and shot a buffalo while their horses ran alongside.

There are numerous indications that they were in north country. The pictograph contains bears and moose, which were found

${ }^{1}$ Garrick Mallery, Picture Writing of the American Indians. Tenth Annual Report of the Bureau of Ethnology to the Secretary or the Smithsonian Institution 1888-89 (New York: Dover Publications, Inc., 1972), v. I, pp. 338, 339, 343, 348; figs. 448, 449, 450, 453, 454, 456.

${ }^{2}$ Ibid., v. I, p. 331 , fig. 438 . 
in Minnesota and Wisconsin but not commonly in Iowa. The probability that the location is Minnesota is supported by the presence of buffalo and prairie chickens, which occurred eastward as far as Wisconsin, but more commonly in Minnesota, as well as in Iowa.

The time is spring, indicated by many clues: a pelican with a knob on its beak, something it has only in spring; a prairie chicken strutting as it does in its spring courtship dance; moose, elk and deer with short antlers. A female deer is shown with "scrambled" insides, a pictographic convention denoting, among other things, that the animal is pregnant, as in fairly early spring. ${ }^{3}$ Trees are leafless. A tadpole is depicted, and a frog. A butterfly is out; a dragon fly out or emerging.

A beaver is shown in a steel trap, a popular article of trade goods since the white man's traps were more effective than any the Indians had. Beaver were usually trapped in the spring, when the pelts were prime and transportation by water to the trading post was easy, or when an itinerant trader might be expected to be making his rounds soon. The set shown is a typical drowning set, with a float stick like those still used by beaver trappers.

Spring hunts were customary among Indians of the region. The hunters would go out in small groups, hunting and trapping, and return with a supply of furs and skins to trade. All evidence within the pictograph suggests that this is the record of such a hunt-the signs showing spring, the beaver being trapped, and the variety of animals shown as having been taken by the hunters. This abundance of wildlife and the good hunting and trapping are clearly shown on one sheet of the pictograph, with a buffalo hunt and fishing exploits on the other.

Lines connect the figure of one Indian with a variety of pictures indicating he got the animals pictured, and still others are shown upside down-dead. ${ }^{4}$ Besides the buffalo shot from running horses, animals taken and shown by the connecting line include lynx (short tail and claws shown), mountain lion (longer tail), bull elk, buffalo, black bear, otter (upside down also), griz-

${ }^{3}$ Ibid., v. I, p. 312, fig. 355 .

${ }^{4}$ William Tomkins, Indian Sign Language (New York: Dover Publications, Inc. 1969), p. 81. Originally published by the author, San Diego, Calif., as Universal Sign Language of the Plains Indians of North America, 1931. 


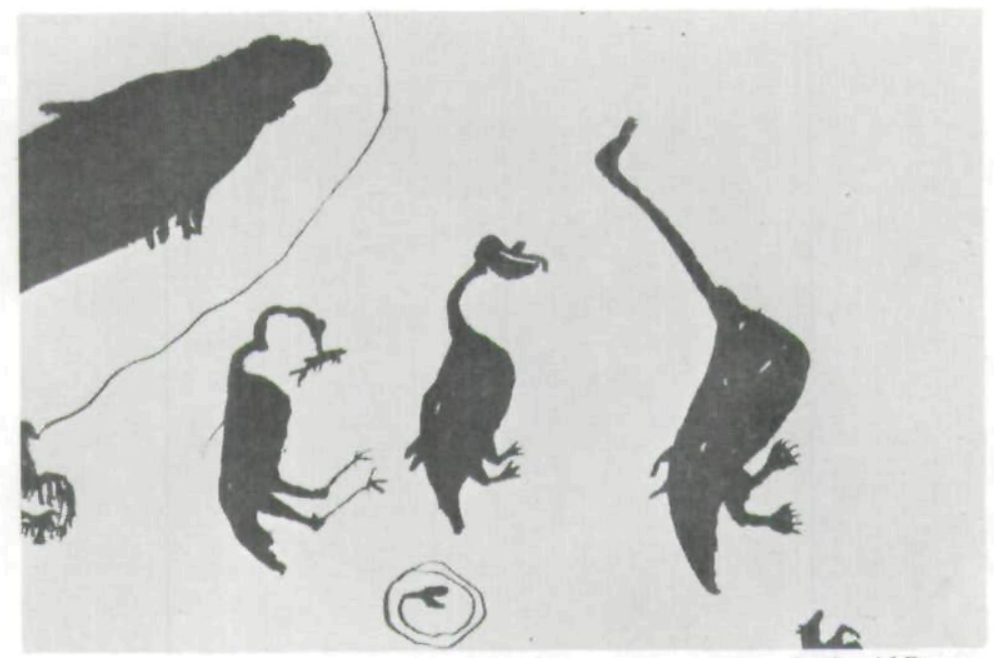

Des Moines Tribune photo by David Penney

Detail from the pictograph showing a heron with a fish, a pelican with a knob on its beak indicating the spring season, and a swan.

zly bear (its claws more prominent), timber wolf, moose (the "bell" of the bull moose clearly drawn), possibly a fisher (upside down), rabbit, snapping turtle, a flying bird with banded tail which may be a golden eagle, and another flying bird with a forked tail which may be a swallow-tailed kite, a kind of hawk formerly found on rare occasions along the Mississippi in Iowa. Animals shown upside down, or dead, include muskrat, skunk, mink, raccoon, possum, the otter (connected with line), timber wolf (connected with line), fox, and an animal that is possibly a fisher (connected with line).

A row of animals shown right side up were probably animals observed but not taken by the hunters. Below the mountain lion is a buck deer and to the left of it a doe; and above the dead animals, reading from right to left, an animal which may be a fawn, a wolverine, woodchuck, badger and probably a cat of some kind. Besides the snapping turtle, the hunting half of the pictograph also shows a soft-shelled turtle and the ordinary hard-shelled turtle. Other birds include: two more hawks-one large, perhaps an eagle, one small-a crane, a ruffed grouse, a strutting prairie chicken and a quail. A bird in front of them is probably a goose or 
swan. Another crane is shown in a corner. A strutting turkey gobbler is near the tree, and above it are a jacksnipe and a woodcock.

In the tree are possum, squirrel, marten, porcupine and grouse, and a chipmunk running up the tree. In the corner behind the elk are a butterfly, a frog and an unidentified figure. In another corner is a mouse, a weasel and an unidentified bird; and in the corner above the tree, a turtle crawling on a bank.

The lynx at far right, connected to the man with a line, is shown running, and with lines emerging from its mouth, a pictographic convention for sound or screaming. ${ }^{5}$ The apparent meaning is that the lynx screamed, charged, and was killed by the hunter while in the act of charging.

As for the hunter himself, he is shown without any hair at all, as was common among the Sauk Indians who had a village on the Rock River in Illinois not far from Col. Davenport's trading post. He carries a bow, with an arrow ready to shoot, and lines on his lower back are probably intended to represent bow case and quiver.

He has just shot a man, using only one arrow-a man who carries a clearly-drawn flintlock rifle and is shown running. The man shot is not a white man, since whites were commonly depicted wearing hats. ${ }^{6}$ Two interpretations are possible for the hair style of this man with a rifle. An old person is sometimes pictured this way, ${ }^{7}$ but more often this type of hair represents an Ojibway. ${ }^{8}$ Since the hunters were probably traveling north, an encounter with a less-than-friendly Ojibway would appear a logical explanation. In some cases, too, the term "Ojibway" has been used to describe any or all enemies; the man with the rifle may, therefore, be merely an enemy of some unnamed tribe. ${ }^{9}$

Whoever the slain man was, the feat of killing him with just one arrow, while he carried a gun, would be a noteworthy achievement, one to be especially remembered and making that particular spring hunt more memorable. The hunter has used one arrow, the reversed barb at the end of the second one perhaps indicating

\footnotetext{
${ }^{5}$ Mallery, op. cit., v. II, pp. 718-719, figs. 1196, 1197, 1199.

'Ibid., v. I, p. 279, fig. 216; p. 313, fig. 357.

'Ibid., v. I, pp. 244, 245.

Ibid., v. I, p. 257, fig. 174

'Ibid., v. I, p. 435.
} 
a magic arrow ${ }^{10}$ or perhaps meaning "I used just one arrow."

The second sheet of the pictograph, which includes the buffalo hunt, deals mostly with fishing. The line which goes through the buffalo is a typical sign for a journey on a stream, and the fork at the end the common way of depicting that this is the direction of travel. ${ }^{11}$

Fish shown at the right of the buffalo are wall-eyed pike, sucker, spoonbill catfish (which is found only in the Mississippi and Missouri Rivers and their larger tributaries), and above the men, a perch. Two men are shown in a canoe, the man in the stern paddling and the one in the bow, standing and spearing a fish. The pictograph shows tines of the spear. The canoe has upswept ends, indicating a birch bark canoe typical of the north country rather than the dugouts used by the Sac and Fox Indians further downstream.

In the corner near the men, a creature is shown swimming, with "sound" lines coming from its head. Best interpretation

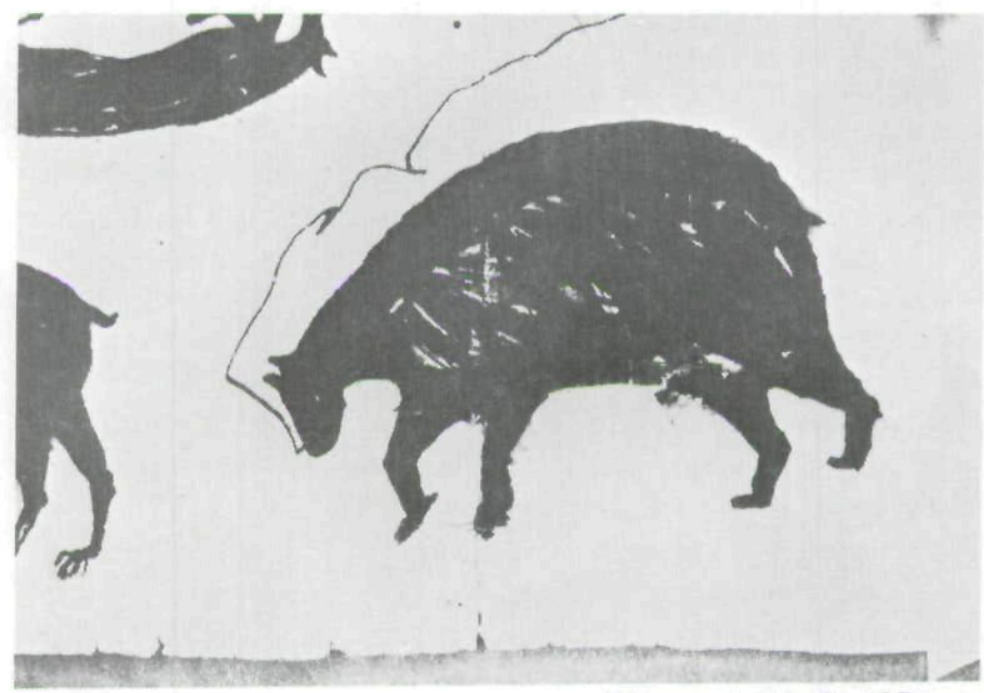

Tribune photo by David Penney

Detail from the pictograph showing a black bear with plantigrade feet.

${ }^{10} \mathrm{Ibid}$., v. II, p. 503, fig. 709.

"Ibid., v. I, p. 331, fig. 438. 
seems to be that this is a loon. Its "pigeon-toed" feet are indicated far back on its body and it does indeed sometimes swim under water by using its wings for propulsion, as shown in the pictograph.

Below the speared fish is a comment on the quality of lifethere were lots of little bugs. Below that is a coiled snake with its mouth open, and below that what is probably another openmouthed snake, swimming or crawling. The big fish just to the left of the bugs is a sturgeon. The biggest fish in the pictograph, near the center, is probably a muskellunge or a northern pike. Ignoring for the moment the bird connected to the man, there are three more birds shown, all water birds: a heron with a fish, a pelican, and a swan. At the edge of the paper, a cow buffalo can be seen. Below are a frog and tadpole and what is probably a toad; near the swan is an unidentified small animal. Near the corner a small animal with a long tail, probably a squirrel, is making a lot of noise, after the manner of squirrels.

Along the bank at the bottom of the sheet, perhaps sitting on a $\log$, is a row of turtles, and just to the left of them a somewhat conventionalized dragon fly. From the number of legs shown on the dragon fly, this may be a nymph stage of the insect rather than adult, indicating it is emerging.

A man is shown seated on the bank, fishing with a pole, something the Indian learned from the white man. He's fishing in a stream, ${ }^{12}$ as indicated by the many wavy lines below him, and in the stream are sheephead or fresh water drum, crappie, a bass he has hooked, sunfish and bullhead. Above him are channel catfish (forked tail), flathead catfish (blunt nose and nearly square tail), fresh water drum, and buffalo fish. Next to these fish, a dogfish and a gar, and behind the fisherman a crane, a spoonbill catfish and on the bank a ground squirrel sits by its hole watching. Below the ground squirrel, a coiled line may be an indication of time elapsed during the trip, more than two months.

Along the lefthand edge, two men are shown fishing with hand lines, as the Indians often did, and using frogs for bait. One of these men also has a bow case and quiver. One unidentified fish is shown. Behind the figure on horseback is another bird, not identified, an unidentified figure on an angled line, and what is

${ }^{12} I$ bid., v. I, p. 344. 
probably another tree.

Again on this sheet, the Indians are shown with no hair. This may be significant, since customarily the Sauks, or Sacs, and Foxes plucked out their hair leaving, at most, a scalp lock. Use of turtles and muskrats, as well as methods of fishing, also suggest the pictograph may be the work of a Sauk Indian, or perhaps a member of the Fox clan, since by this time the two groups were living together, as they do now.

In the center of the sheet, an Indian with bow case and quiver is shown standing behind a tree, using a gun to shoot another man. This man and the hand line fishermen also appear to be wearing leggings. Behind the man with the gun, a row of dots indicates a long trail; ${ }^{13}$ he has followed the man he shot, probably for a long time and long distance, and then hid behind the tree and shot him. A line is attached to the top of this man's head, and at the other end of the line is a bird, a typical way of depicting a man's personal totem or identification, with a line coming from the top of his head or from his mouth. ${ }^{14}$ In this case, the bird identifying the man in the pictograph gives rise to some interesting speculation, since it is a small black bird with a banded tail and carries another very small bird in one foot. The best explanation seems to be that the bird is a hawk, and the black coloration, banded tail and small bird in its talons suggest a bird now known as a pigeon hawk but formerly known as a black sparrow hawk.

Black Hawk, a great leader of the Sauk tribe, who lived on the Rock River near Davenport's trading post, had an Indian name Ma-ka-tai-me-she-kia-kiah, ${ }^{15}$ which is properly translated as Black Sparrow Hawk. George Catlin, an artist who painted Indian portraits, calls Black Hawk Muk-a-tah-mish-o-kah-kiak and refers to him as "the leader of the 'Black Hawk War.'" When Catlin painted Black Hawk, while he was in prison at Jefferson Barracks in 1832 after the war, according to Catlin's notes Black Hawk was "dressed in a plain suit of buckskin, with strings of wampum in his ears and on his neck, and held in his hand his medicine-bag, which was the skin of a black hawk, from which he

${ }^{13}$ Ibid., v. I, p. 342, fig. 452 .

${ }^{14}$ Ibid., v. I, pp. 419-459.

${ }^{15}$ Antoine LeClaire, translator, Life of Black Hawk (Boston, 1834), p. 6. 
had taken his name, and the tail of which made him a fan."

In the accompanying plate ${ }^{17}$ in the writers' edition of Catlin, the tail of the hawk is shown as all black. The plates in the original of Catlin's book, from which this edition was printed, however, were hand-colored engravings, not photographic reproductions of his paintings, a process not then available. A more recent book on Catlin shows the hawk Black Hawk is holding as black and the tail, used as a fan, as banded black and white. ${ }^{18}$ It seems

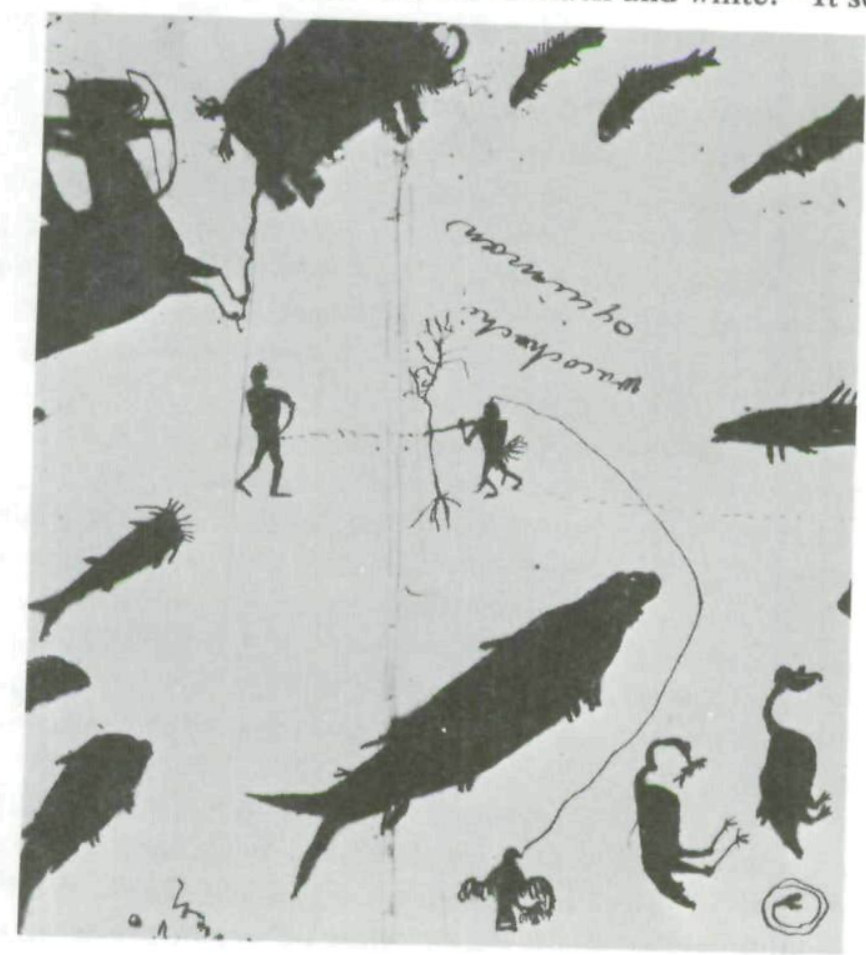

Tribune photo by David Penney

Detail showing one man (with line running from his head to a totem symbol for black hawk) shooting another.

${ }^{16}$ George Catlin, North American Indians, Being Letters and Notes on Their Manners, Customs, and Conditions, Written During Eight Years' Travel Amongst the Wildest Tribes in North America, 1832-1839 (Edinburgh: John Grant, 1926), v. II, p. 239.

${ }^{17}$ Ibid., p. 283.

${ }^{18}$ Harold McCracken, George Catlin and the Old Frontier (New York: Bonanza Books, The Dial Press, Inc., 1959), p. 164. 
probable, on the basis of this evidence, that the Indian pictured is indeed Black Hawk, but there is no way to be entirely sure.

Most Indians had more than one name, and each had a secret name, very sacred, which was his true name, often received as a result of meditation. Other names were bestowed at various times for various reasons and a man wasn't always known by the same name all of his life, nor was he always called the same name by everyone who knew him. Another problem with Indian names in early records arises from the fact that they were written down phonetically as they sounded to the person making the record, so several spellings might be used for the same name.

In white man's hand, two words are written on the pictograph: "wacochachi," and below that "oquiman." At one edge, someone has laboriously copied "wacochachi," in script which looks almost as if the writer's hand had been guided by someone else. And just to the left of the tail of the muskellunge, both words are written, so badly as to be barely distinguishable, with "wacochachi" above "oquiman." In this case, it looks as if somebody tried to copy the well-written words and made a bad job of it.

Nowhere in the literature does either of these words, or anything like them occur in relation to Black Hawk. The possibility then arises that "wacochachi" is the name of someone else, perhaps the second Indian in the pictograph. If "oquiman" were part of his name, it would logically be written on the same line; written below the name, as it is, the possiblity arises that this is either another Indian or a title. On the pictograph, it appears that perhaps some white man wrote the name or names, an Indian tried to copy the signature and had trouble (in the marks near the muskellunge's tail), and the white man then guided his hand in signing the pictograph. Following this line of speculation, a search was begun for a Sauk or Fox Indian with a similar name.

A check of Indian treaties dated 1836, 1837 and 1842 suggests that "wacochachi," the first of these words, is probably the name of a member of the Fox clan who signed these treaties.

On September 27, 1836, one of the signers of a treaty was "Wa-ko-sa-see, his X mark." ${ }^{19}$ This treaty is "between Henry Dodge, Superintendent of Indian Affairs, and the chiefs, braves, and principal men of the Sac and Fox tribe of Indians," and is

${ }^{19} \mathrm{Knapper}$ Indian Affairs, v. 2, p. 473. 
signed by such historic personages as H. Dodge; James W. Grimes, secretary to the commission; Joseph M. Street, Indian agent; Antoine St. Clair (LeClaire), interpreter; and George Catlin. Indian notables who signed included "Po-we-seek" (Poweshiek), "Keo-kuck" (Keokuk), "Ap-pi-nuis" (Appanoose), and Pa-she-pa-ho.

Another treaty was dated the following day, September 28, 1836 , "at the treaty ground on the right bank of the Mississippi, in Dubuque county, Wisconsin Territory, opposite Rock island," ${ }_{20}$ and here the name appears as "Wa-ka-sha-she, his X mark." Indian signers of this document include "Wa-pella" (Wapello) and 'Pow-a-seek" (Poweshiek) among the Foxes, and "Kee-o-kuck" (Keokuk), Pashepahoo, and Ap-a-noose (Appanoose), identified as Sacs or Sauks. Historic figures among white signers were Dodge, Grimes, Street, LeClaire, P. R. Chouteau, jr., George Davenport and Catlin. Catlin also refers to these treaties, failing to say that he was one of the signers, and mentions, among the Indians present, only Black Hawk (who was not allowed to sign), Black Hawk's aide, Nah-pope, and Keokuk. ${ }^{21}$

In a treaty signed in "the city of Washington" on October 21, 1837, the name "Waa-co-shaa-shee, Red Nose Fox, a principal chief Fox tribe, (wounded,)" appears on the list of those signing. ${ }^{22}$ Other well-known Indians who signed this treaty include "Kee-o-kuck [Keokuk], The Watchful Fox, principal chief of the confederated tribes, .... Appan-oze-o-k-mar [Appanoose], The Hereditary Chief (or He who was a Chief when a Child) . . . Wapella [Wapello], The Prince, a principal chief, . . . Po-we-sheek [Poweshiek], Shedding Bear, a (principal chief) ..." Among whites who signed were Street, Davenport and LeClaire.

In a treaty signed "at the Sac and Fox Agency, in the Territory of Iowa," October 11, 1842, "Wa co sha she" is one of the Foxes who signed. ${ }^{23}$ Important Sacs listed as signers are "Ke o kuk," "Ke o kuk, jr.," and "Ap pe noose;" "Pow a chick" is another of the Foxes who signed.

A letter from Joseph M. Street, Indian agent, to Governor Dodge, dated Rock Island, 27 August, 1837, concerning a battle between a band of Foxes and the Sioux also mentions this Indian,

${ }^{20}$ Ibid., p. 475.

${ }^{22}$ Knapper, op. cit., p. 496.
${ }^{21}$ Catlin, op. cit., pp. 244-246.

${ }^{23}$ Ibid., p. 548. 
and a "talk" he sent with two of his young men in reporting the battle:

Sir, After a full conversation with Pow-sheek and the Principal Chief of the upper band of Foxes, who with several braves who were in the late battle with the Sioux are now at this Agency, I am enabled to report their account of the affair.

Pow-sheek had remained at his village on Red Cedar, [near the present town of Atalissa] and the portion of the band that went out, consisting of about 200 men with a large number of Women \& children, was led by Wa-co-sha-see, the had (sic) War-chief of the band. They say they went out on their summer hunt to procure means of subsistance and Waco-sha-see divided the band into two parties, better to enable them to hunt and sustain themselves... they came upon country hunted by Winnebeagos, and where they were then hunting \& Wacoshasee \& his party crossed to the West of the Cedar below Otter River . . . \& crossed Otter River sending a party ahead who returned and reported the discovery of a large Sioux trail. The Foxes camped their women .... sent on Spies .... and lay by until just before day, and then moved on to fall directly on the lodges. . .

The Sioux, it turned out, weren't camped where the Foxes thought they were, and the Foxes "then discovered after great loss that the Sioux had dug holes in and about their lodges and were thereby secured from the Fox fire." The letter continued:

They left all men dead \& brought off 13 wounded, none of the wounded are dead since and all but one seem like recovering. They thought Wa co shashe would die for some time as was shot in body and Spate blood, he is now rapidly recovering \& soon will be well.

The Foxes declare that the battle ground is within their country. . . .

The Indians say Wa-co-sha-see, sent in a talk to be delivered to me, and not finding me at the Island at the time the two braves came in, they delivered it to Mr. Davenport their Trader, and desired him to write it down and send it to me,- - that the talk read to them contains the same facts in their talk from Wa-co-sha-see. Mr. Davenport says he put it on the post office directed to me at Prairie du chien the 20 Augt (instant) on the same day he sent a copy of it to the printer at Galena, not expecting the printer to publish his letter, but the talk alone. The talk sent by $\mathrm{Mr}$. Davenport to me I have never seen \& cannot account for it. The talk in the papers I used in conversing with the Indians. ${ }^{24}$

Davenport's translation of the "talk," along with his letter concerning it, appeared in the Galena Weekly Gazette, as Street indicated, on Saturday, August 18, 1837. It is quoted below.

${ }^{24}$ John Porter Bloom, The Territorial Papers of the United States, vol. XXVII, The Territory of Wisconsin, Executive Journal, 1836-1848, Papers, 18361839 (Washington: The National Archives, 1969), pp. 841-843. 
INDIAN LODGE, Rock Island, August 10, 1837. Dear Sir.-I enclose you a talk delivered to me by two braves of the upper band of Fox Indians, by the request of their war chief, Wa-co-shash-he, who has been mortally wounded in a late encounter with the Sioux, on the Sac and Fox hunting grounds, requesting me to forward it to Gen. J. M. Street; to you I send a copy to publish if you think proper. . . .

Respectfully your Friend, Geo. Davenport

To Gen. J. M. Street: My Father-I send two of my young men to tell you the news. When I returned from Saint Louis, I found our people starving at the village-I divided all the provisions I had received from our trader among them, and the powder and lead to enable us to make a hunt to supply our families until our corn was ripe, . . 25

An account of the hunt and the encounter with the Sioux follows, as presented in Street's report.

My Father,-I am one of the wounded, and expect never to see you again. I have followed your advice, and have done the best I could for my
nation. . . .

My Father, I have no more to say, WAU-COSH-AU-SHE, Principal War Chief of the Foxes.

Wacochachi did not die, of course. His name, spelled Waaco-shaa-shee, appears on a treaty signed in Washington, D.C. that year with the notation that he was wounded, and again, this time spelled Wa co sha she, on the 1842 treaty. He is also on Street's list of Indians who made the 1837 trip to Washington. ${ }^{26}$

A careful reading of Davenport's full text of the talk, and Street's report of the trouble with the Sioux, indicated that the talking paper preserved by Davenport and now in the Historical Department is not the one mentioned in these two records, but another. Nowhere in the Department's pictograph is there any indication of a large number of people in a hunting party; probably just two. The Department pictograph is clearly a spring expedition, while Street's report involves a summer hunt. The only violence in the pictograph in the Historical Department relates to the killing of single enemies, possibly Ojibways, rather than several Sioux. Nowhere in the Department's pictograph is there any suggestion that someone from the "writer's" tribe was killed or injured, as happened in the encounter with the Sioux. Nor is there any indication that any women were along. And Street's report

\footnotetext{
${ }^{25}$ Galena Weekly Gazette, August 18, 1837, Archives of the Illinois State Historical Library.

${ }^{26}$ Bloom, op. cit., p. 860 .
} 
mentions only hunting, no trapping, while the Department's pictograph shows hunting, fishing, and trapping. Clearly the thrust of the Department's pictograph concerns these items rather than the two isolated killings shown; the "talk" sent to Street was a report of a battle, not a hunt. Apparently Wacochachi used "talking papers" more than once to send or give messages to his white brothers.

As for the various names given, all are phonetic spellings, differing even when they appear on treaties signed on successive days or on a single list of Indians taken on a trip to Washington. How. ever, when pronounced, the name was easily recognized by a present-day member of the tribe, Edgar Poweshiek of Tama, as one of the great leaders of the past.

But is Wacochachi of the pictograph the same man? First, a check of Davenport's ledgers shows that the handwriting on the pictograph is probably his, the $c h$ being distinctive. ${ }^{27}$ Second, Davenport's earliest ledger is written in French, a language in which $c h$ is pronounced about the same as the English $s h$. Giving the name in the pictograph, Wacochachi, a French pronunciation, it sounds about the same as the English pronunciation of Wa-ko-sa-see, Wa-ka-sha-she, Waa-co-chas-shee, Waucochache, Wau-soch-au-she, Wa co sha she, Waco-sha-she, and Wa-kosha-she, an important leader of the Foxes. There seems to be little question this is the name on the pictograph.

In Davenport's later records, written in English, the name "Waco" appears several times, and this may be the same Indian, but the full name Wacochachi wasn't found anywhere in the ledgers, nor any Anglicized spelling of the name.

In a history of Johnson County published in 1883, there are references to a sub-chief of "the Musquaka branch of the Sac and Fox Tribe" by the name of Wapashashiek. According to the history, when white men arrived in the area in 1836, they found Poweshiek and his people occupying a village in what later became Pleasant Valley township on the east side of the Iowa River, south of where the town of Napoleon was later situated, and between the river and the place where John Gilbert established a trading post. Wapashashiek had his village about a mile up the

${ }^{27}$ George Davenport, Ledgers. Photostatic copies in the Library of the Iowa Department of History and Archives, Des Moines. 
river from Poweshiek's site, closer to Napoleon. ${ }^{28}$

Wapashashiek was characterized as strictly just and honest, as was Poweshiek; and while Poweshiek was said to be fond of whiskey, Wapashashiek was said to be sober. He was a "tall, thin, spare man; had far less executive talent and weight of character than Poweshiek. . . ." He was, nevertheless, a person of importance. ${ }^{29}$

According to the history, in the spring of 1839 Poweshiek moved his village to near the west line of what is now Monroe township, and about the same time Wapashashiek moved to a new agency and trading post five miles below Marengo; the following year Poweshiek and his people went there also. In 1843 all of these Indians were moved to Fort Des Moines, ${ }^{30}$ and in 1845 and 1846 most of them went to a reservation in Kansas. The history says that Wapashashiek's age and birthplace were unknown. Whether he was still alive for the move to Fort Des Moines is not indicated. ${ }^{31}$

Allowing for peculiarities in phonetic spelling of Indian names, his status as a sub-chief, plus the fact that forty years were to elapse before the county history was written, which is ample time for corruption of the name as it was passed along by word of mouth, it seems reasonable to assume that the Wapashashiek of Johnson County history, the man who signed the four treaties, the Indian who sent Street a "talk" and Wacochachi of the pictograph are all the same man. He may be the Indian who drew the pictograph; he may be one of the Indians pictured; he may be the person who gave the pictograph to Davenport. There is no way, now, of knowing for sure.

The word "oquiman" probably refers to Wacochachi's title as a chief. One signer of an Indian treaty, in 1825, was a Menominee "o-que-men-ee," which was translated as meaning "the little chief." ${ }^{32}$ In LeClaire's autobiography, Black Hawk is quoted as calling General Atkinson "General Oke-Maut," the word here meaning a general or chief. ${ }^{33}$ The phonetic similarity, plus the

\footnotetext{
${ }^{28}$ History of Johnson County, Iowa (Iowa City, 1883), pp. 206, 207, 290, 301.

${ }^{29}$ Ibid., pp. 290, 291.

${ }^{30}$ Ibid., p. 291.

${ }^{31} I$ bid., pp. 290, 291.

${ }^{32}$ Knapper, op. cit., p. 254.

${ }^{33}$ LeClaire, op. cit.
} 
fact that "oquiman" is written below rather than after "Wacochachi," suggests that this is his title. Edgar Poweshiek confirms translation of "oquiman" as some kind of chief.

The question of just why the pictograph was drawn leads to an interesting line of thought. It may be simply a record of an unusually successful and eventful spring hunt, with Black Hawk perhaps one of the Indians participating. Or it may be a typical boasting sheet in which an Indian has attempted to show the trader what a great hunter and fisherman he is, perhaps in hopes of obtaining more liberal credit toward his next hunt. The possibility that one of the figures depicted is Black Hawk and that another important Indian, Wacochachi, was involved, may explain why somebody, probably Colonel Davenport, kept the pictograph a long time until it became worn and dog-eared, and finally put it away for safe keeping in a book.

The pictograph is interesting, of course, not only for its historic value, artistic merit and age, but also for the fact that, after such a very long time, so many of the animals, birds and fish are so well drawn, with distinguishing characteristcs so clearly defined, that it is possible to read most of it with confidence that the reading is accurate.

The pictograph was probably meant not so much as a picture but as a story-telling record, and while its exact meaning and the reason for drawing it will never be known for sure, it is so well done that after about a century and a half Chemokemon, the white man, can read most of it. ${ }^{34}$

Therein lies much of its historic value. Using the obvious information from the pictograph, it is possible to reconstruct just what kinds of birds and animals were normally encountered on a spring hunt such as this, what fish and game the Indians normally took on these trips, and even their methods of hunting and trapping. Also remarkable is the breadth of the Indian's observation; very little wildlife, either large or small, escaped observation. They are all recorded in the pictograph, right down to pesky little bugs.

The pictograph in all probability dates from the 1820 s or early 1830s. Davenport was already well established as a trader by that

${ }^{34}$ Catlin, op. cit., p. 246. 
time. Use of a clearly-drawn flintlock rifle tends to confirm the early date. The worn condition of the pictograph, and the fact the ink has eaten into the paper, also suggest that it is quite old.

The latest date for the pictograph is probably about 1845 , since Davenport was murdered by robbers at his home on the Island July 4, 1845. Black Hawk came to public attention during the Black Hawk War in 1832 and died in 1838. If he is the Indian pictured, as seems likely, then a fairly early date for the pictograph is reasonable, allowing of course for the fact that the artist who drew the pictures might have been recalling an earlier spring hunt with Black Hawk even after the mighty war leader was dead. ${ }^{35}$

The pictograph has been framed and is on exhibit in the State Historical Building in the Davenport room, which houses other historic items connected with the Davenport family.

\footnotetext{
${ }^{35}$ Other sources used in this article include the following: Helen M. Blish, $A$ Pictorgraphic History of the Oglala Soux (Lincoln: University of Nebraska Press, 1967); Des Moines Sunday Register Picture Magazine, November 29, 1959, p. 13; Campbell Grant, and James W. Baird and J. Kenneth Pringle, Rock Drawings of the Coso Range, Inyo County, California (China Lake, California: Maturango Museum, publication 4, 1968); Campbell Grant, Rock Art of the American Indian (New York: Thomas Crowell Co., 1967); Marshall McKusick, Ancient Iowa Lives On In Indian Rock Drawings (The Iowan, Vol. 11, July 5, 1963), pp. 40-45; W. W. Newcomb, jr., The Rock Art of Texas Indians (Austin, Texas: University of Texas Press, 1967; Polly Schaafsma, Early Navaho Rock Paintings and Carvings (Museum of Navajo Ceremonial Art, Inc., 1966); P. Schaafsma, The Rock Art of Utah (Cambridge, Massachusetts: Papers of the Peabody Museum of Archaeology and Ethnology, Harvard University, vol. 65, 1971); P. Schaafsma, Southwest Indian Pictographs and Petroglyphs (Museum of New Mexico, 1965); Frank Waters, Book of the Hopi (New York: Ballantine Books, Inc., 1963).
} 
Copyright of Annals of Iowa is the property of State of Iowa, by \& through the State Historical Society of Iowa and its content may not be copied or emailed to multiple sites or posted to a listserv without the copyright holder's express written permission. However, users may print, download, or email articles for individual use. 